\author{
Alicja Zakrzewska-Póltorak \\ Wroclaw University of Economics and Business \\ e-mail: alicja.zakrzewska-poltorak@ue.wroc.pl \\ ORCID: 0000-0002-5752-0002
}

\title{
DIFFERENCES IN THE PRICES OF RESIDENTIAL PREMISES ON THE PRIMARY AND SECONDARY REAL ESTATE MARKET IN WROCLAW BETWEEN 2010 AND 2017
}

\section{RÓŻNICE W CENACH LOKALI MIESZKALNYCH NA RYNKU PIERWOTNYM I WTÓRNYM WE WROCŁAWIU W LATACH 2010-2017}

\author{
DOI: $10.15611 /$ br.2019.1.18 \\ JEL Classification: O18, R21, R31
}

\begin{abstract}
Summary: The purpose of the paper is to discuss the differences in the mean transaction price of $1 \mathrm{~m}^{2}$ of residential premises in selected territorial units of Wrocław (Poland) between 2010 and 2017, divided according to data from sales agreements on the primary and secondary market and depending on the usable area of the flat. The methods used in the paper include a descriptive method, simple statistical methods (e.g. coefficient of variation) and components of financial analysis. The data were taken from the AMRON Centre database and from Statistics Poland. In 2010-2017 the high demand for flats in Wrocław placed producers on a stronger position than buyers. Analysis revealed that the prices of bigger flats showed greater volatility over time than prices of smaller ones. Moreover growing differences in the average transaction price of $1 \mathrm{~m}^{2}$ of residential premises between flats constructed using new and old technology were observed, especially in the case of the larger ones.
\end{abstract}

Keywords: real estate market, residential premises, primary market, secondary market, mean transaction square metre price, Wrocław.

Streszczenie: Celem artykułu jest omówienie różnic w średniej cenie transakcyjnej $1 \mathrm{~m}^{2}$ lokali mieszkalnych w wybranych jednostkach terytorialnych Wrocławia w latach 2010-2017 według danych z umów sprzedaży na rynku pierwotnym i wtórnym oraz w zależności od wielkości powierzchni użytkowej mieszkania. W pracy zastosowano metodę opisową, proste metody statystyczne (np. współczynnik zmienności) oraz elementy analizy finansowej. Wykorzystano dane z bazy danych Centrum 
AMRON i Głównego Urzędu Statystycznego. W latach 2010-2017 wysoki popyt na mieszkania we Wrocławiu plasował producentów na silniejszej pozycji niż kupujących. Analiza wykazała, że ceny większych mieszkań wykazywały większą zmienność w czasie niż ceny mniejszych lokali mieszkalnych. Ponadto zaobserwowano rosnące różnice w średniej cenie transakcyjnej $1 \mathrm{~m}^{2}$ lokali mieszkalnych między mieszkaniami zbudowanymi w nowej i starej technologii, zwłaszcza w przypadku mieszkań większych.

Słowa kluczowe: rynek nieruchomości, lokale mieszkalne, rynek pierwotny, rynek wtórny, średnia cena transakcyjna za metr kwadratowy, Wrocław.

\section{Introduction}

The purpose of the paper is to discuss the differences in the mean transaction price of $1 \mathrm{~m}^{2}$ of residential premises in selected territorial division units of Wrocław ${ }^{1}$ (also called the city's territorial units for statistics, so called delegatury [divisions] or former dzielnice [districts]) between 2010 and 2017, divided according to data from sales agreements on the primary and secondary market and depending on the usable area of the flat. The study was carried out in three territorial units of Wrocław: Fabryczna, Krzyki and Psie Pole. The other two: Stare Miasto (Old Town) and Śródmieście were excluded due to the fact that the number of transactions recorded in the database each year (less than 20 transactions a year in each category) was too low. The methods used in the paper include a descriptive method, simple statistical methods, including descriptive statistics (e.g. coefficient of variation) and components of financial analysis (the data were converted into fixed prices, with 2010 being the baseline). The data were taken from the AMRON Centre (Centre for Analysis and Monitoring of Real Estate Market) database and data from Statistics Poland (e.g. from the Local Data Bank database).

The studied residential premises were divided according to their usable area and the following groups were identified: $30-50 \mathrm{~m}^{2}, 51-70 \mathrm{~m}^{2}, 71-90 \mathrm{~m}^{2}$ and $91-130$ $\mathrm{m}^{2}$. A detailed examination was carried out of the prices of the smallest premises (the first category) and fairly large ones - with the area of 71-90 $\mathrm{m}^{2}$ (the third category). The first group covers residential premises of two rooms ${ }^{2}$ whose share in the general number of residential premises sold in Wrocław amounted to circa 30\% in 2017, while the other group includes flats with four or more rooms whose share was approximately $21 \%$ [Local Data Bank...].

The paper consists of five sections, the Introduction and Conclusions. The first section presents theoretical issues concerning real estate market prices. The second

${ }^{1}$ Wrocław is a city in Poland. It has over 641,000 people (end of June 2019, the Local Data Bank Statistics Poland). It is the capital of the region of Lower Silesia (one of the Polish voivodeships). It is one of the well-developed cities in Poland. In 2016 Wrocław generated approximately $2.7 \%$ of GDP in Poland. In terms of purchasing power standards (PPS), it was over $110 \%$ of average GDP per capita in the European Union (according to the data of Statistics Poland and Eurostat).

${ }^{2}$ A room means a living room, bedroom or kitchen. 
part discusses the dynamics of changes in the mean transaction price of residential premises in Wrocław versus the dynamics of changes in the prices of consumer goods and services in Poland and against the dynamics of changes in the mean gross salary in Wrocław. Then the differences are presented in the mean price of a flat built using new and old technology in Wrocław, i.e. selected residential premises built after 2005 and in high-rise blocks of flats built in the period between the 1950s and 2005. The key third section analyses the mean fixed transaction prices per $1 \mathrm{~m}^{2}$ of residential premises between 2010 and 2017. The study covered premises built after 2005 which were the subject of primary and secondary market transactions, and located in the former districts of Wrocław: Fabryczna, Krzyki and Psie Pole, including the usable areas of the flats. The fourth part presents a comparison of mean prices (analysed in the third part) in a territorial and typebased arrangement. To that end a coefficient of variation of fixed prices of 2010 was applied. The fifth section is a discussion about the research results. The paper ends with Conclusions.

\section{Theory outline - prices and preferences on real estate markets, periodicity, price variation determinants}

The real estate market is specific among the markets identified in economy. It has a number of features of an imperfect market. This status is mainly determined by the specificity of real estate as such, which is characterised by features that make it stand out among other goods. The features include immobility, capital intensity, durability, indivisibility, complexity in a physical sense and difficulty related to comparability of individual objects [Kucharska-Stasiak 1997]. The imperfection of real estate markets results primarily from low price elasticity (relatively fixed prices, delayed supply and demand response to changes in the economic outlook) and difficulty in achieving balance [Meen 2016].

Real estate markets are cyclical and they tend to respond strongly (though with a delay) to changes in the economic situation. Fluctuations observed in the economy, including real estate markets, are divided into: business fluctuations, incidental fluctuations and periodical (seasonal) fluctuations, but there is also the so-called development trend (increase or decrease) [Trojanek 2011]. Residential property cycles are important for the real estate market - they can be defined as irregular, recurring fluctuations in the level of total income from all kinds of real estate, which is also reflected in other real estate market indicators [Key et al. 1994].

The local market of residential premises in selected districts of Wrockaw is the subject matter of the study. The reference market is characterised by the following (see: [Meen 2001]):

- the aforementioned imperfection, including low price elasticity of supply and demand, 
- non-homogeneity (need to develop analyses for different market segments, according to location, property type, investing entities etc.),

- low effectiveness (the price hardly reflects the real value of the property because the market is not very transparent and drawing conclusions from past periods can lead to wrong decisions),

- low liquidity (it is difficult to sell property quickly),

- high income elasticity of demand for flats,

- irrational actions of some market participants (at least from the economic point of view).

The differences in the prices on real estate markets depend on subjective and objective factors. This applies to the market of residential premises. The subjective factors include the taste of the buyers, preferences related to the household life cycle stage and the effect of following others (the bandwagon effect). The objective ones are the relationship of the transaction price of residential premises to its features (such as technical and physical features of the real estate, real estate management quality, location etc. [Sirmans, Macpherson, Ziets 2005]), investors' level of income and income level changes, mean price of a square metre of real estate on other local markets and the return rate on a different kind of investment.

Since the 1980s, imbalance and adaptation to the market have been the main subject of studies described in the literature in reference to the real estate market [Weibull 1983; Maclennan, Munro, Wood 1987]. Though the market is regarded as non-homogenous, its segments and submarkets are homogenous (see e.g. [Goodman 1981; Shiller 1991]). The Weibull dynamic stock-flow model [1983] and the models developed by Maclennan and $\mathrm{Tu}$ [1996] and Tu [1997] which attempt to identify long-term pricing try to offer solutions to the problem of imbalance. The following three scenarios can take place on homogenous submarkets and in homogenous segments [Maclennan, Tu 1996; Tu 1997]:

1) directions of price changes in individual markets and segments are similar, e.g. the price of $1 \mathrm{~m}^{2}$ goes up in all submarkets/ all segments,

2) the prices in individual submarkets or segments strive for equalisation,

3) the differences between submarkets/segments increase (some demonstrate a price increase, while others - a price decrease).

The basic determinants of price diversification analysed in the literature of the subject include [Tu 1997]:

- buyers' preferences,

- demographic changes,

- development of transport infrastructure and public transport,

- location of new housing investments,

- revalorisation of damaged, decapitalised buildings and residential premises,

- changes in the local economic outlook versus the surroundings. 
It should be noted that the process of looking for residential premises tends to be of sequential and hierarchical nature; one is looking for a flat in a specific location, e.g. a district or one of the selected residential estates and meeting particular demands, e.g. a flat with a terrace and garage with a usable area of 90-100 $\mathrm{m}^{2}$, and when one does not find a satisfactory solution, the process starts again but either a different location or another market segment is taken into account (e.g. if it turns out that one cannot afford it, the search begins for a cheaper alternative). Sometimes it suffices to change the location while leaving the flat parameters unchanged but sometimes the parameters also have to be changed.

When analysing the pricing determinants, studies pertaining to the supply side also need to be quoted. The supply of residential premises in a particular local area, e.g. a residential estate or part of the city is often non-elastic, which means it poorly responds to changes in square metre prices. This results from a lack of free areas of land and flats available for sale (which is caused e.g. by the effect of time-consuming and relatively high prices related to the transfer ownership of a flat) [De Palma, Picard, Waddell 2007], though it can also be attributed to the expected price increase [Meen 2016].

\section{Differences in the prices of buildings constructed using old and new technology in Wroclaw}

In the study period (2010-2017) the prices of flats in Wrocław were increasing but less rapidly than the average prices of consumer goods and services, which means that real prices of residential premises were falling. This applied to flats built using new and old technology, whereby the decrease in the mean $1 \mathrm{~m}^{2}$ real price was faster for older residential premises. Moreover, the real average gross salary according to the prices of 2010 was increasing in Wrocław since 2013, and since 2015 it was growing highly dynamically compared to the rest of the country and the Dolnośląskie region, while in 2017 it was nearly 1,000 PLN higher in real terms than in 2010 [Local Data Bank... 2019]. This is testimony to the growing purchasing power of the potential investors on the real estate market in Wrocław.

The transaction prices of $1 \mathrm{~m}^{2}$ of residential premises in Wrocław made using old and new technology are compared below. The comparison includes flats with a usable area of $30-50 \mathrm{~m}^{2}$ and $71-90 \mathrm{~m}^{2}$. Fixed prices of 2010 were employed; in order to convert the variables to comparability, the annual values were used of the retail price index for consumer products and services in Poland, quoted by Statistics Poland. The first category included flats built between 2006 and 2017 - in order to ensure greater comparability, cold shell buildings were eliminated - only the prices of flats on the secondary market were analysed, i.e. finished and often furnished flats. The other parameters of interest included: 
- structure of the building: masonry (hollow brick),

- low-rise multi-family buildings,

- ownership.

The other category covered residential premises purchased on the secondary market, built between 1950 and 2005, with the following parameters:

- structure of the building: any technology,

- residential premises in high-rise blocks of flats,

- ownership.

Table 1 presents the mean prices of smaller and bigger flats in new low-rise buildings and high-rise blocks of flats.

Table 1. Mean transaction price of $1 \mathrm{~m}^{2}$ of residential premises according to fixed prices of 2010 - comparison of two categories of flats based on their construction technology (in PLN $\left./ \mathrm{m}^{2}\right)^{*}$

\begin{tabular}{|c|c|c|c|c|}
\hline \multirow{2}{*}{$\begin{array}{c}\text { Transaction } \\
\text { year }\end{array}$} & \multicolumn{2}{|c|}{$30-50 \mathrm{~m}^{2}$} & \multicolumn{2}{c|}{$71-90 \mathrm{~m}^{2}$} \\
\cline { 2 - 5 } & $\begin{array}{c}\text { low-rise mul- } \\
\text { ti-family building }\end{array}$ & $\begin{array}{c}\text { high-rise block } \\
\text { of flats }\end{array}$ & $\begin{array}{c}\text { low-rise multi-fami- } \\
\text { ly building }\end{array}$ & $\begin{array}{c}\text { high-rise block } \\
\text { of flats }\end{array}$ \\
\hline 2010 & 6435.76 & 6136.29 & 5358.39 & 4751.89 \\
\hline 2011 & 6704.16 & 5653.26 & 6468.91 & 4396.16 \\
\hline 2012 & 5638.08 & 5453.93 & 5072.56 & 4164.26 \\
\hline 2013 & 5312.27 & 5062.18 & 5061.37 & 4017.49 \\
\hline 2014 & 5348.30 & 4998.99 & 4849.30 & 3870.72 \\
\hline 2015 & 5468.98 & 4980.80 & 5495.80 & 3792.87 \\
\hline 2016 & 5474.95 & 4836.01 & 5435.75 & $\mathrm{n} / \mathrm{a}$ \\
\hline 2017 & 5230.27 & 4571.69 & 5569.95 & $\mathrm{n} / \mathrm{a}$ \\
\hline
\end{tabular}

* In 2013 the mean price for an older flat (71-90 $\left.\mathrm{m}^{2}\right)$ was calculated as an arithmetic mean of the average price for premises of that kind from 2012 and 2014 due to the insufficient number of transactions in the database.

Source: own study based on data from the AMRON Centre database and data from Statistics Poland.

The differences between the years in the price of $1 \mathrm{~m}^{2}$ for larger area flats, in favour of newer flats (built after 2005) were significantly greater. Moreover, since 2015 the mean price of a flat with an area of 71-90 $\mathrm{m}^{2}$ constructed using new technology in a low-rise multi-family building was rising in real terms. In the case of flats with an area of 30-50 $\mathrm{m}^{2}$, the difference between the new and old construction technology was lower but it was increasing gradually after 2012 in favour of flats build according to new technologies.

When comparing the difference in the price of $1 \mathrm{~m}^{2}$ in small and big residential premises one should note that it applied only to flats in the old construction technology high-rise blocks of flats. In the case of newer low-rise multi-family buildings, the price of $1 \mathrm{~m}^{2}$ was similar, regardless of the flat's size. 


\section{Prices of residential premises with a usable area of $30-50 \mathrm{~m}^{2}$ and $71-90 \mathrm{~m}^{2}$ on the primary and secondary market in the Fabryczna, Krzyki and Psie Pole districts of Wroclaw between 2010 and 2017}

The following section focuses on three territorial units of Wrocław (former city districts). The Fabryczna unit is situated in the west of Wrocław. It is the largest part of the city for its area and population. At the end of 2017 the population density amounted to 1,736 persons $/ 1 \mathrm{~km}^{2}$, which ranked it as the penultimate of all the territorial units of Wroclaw for population density. In 2017 its share in the total number of flats commissioned in Wrocław was $28 \%$, which was also similar for the total area of the commissioned flats $-29 \%$. Krzyki was another area of interest. This is a former district situated in the south of Wrocław - the smallest and the most densely populated of the three studied districts (as of the end of 2017 there were over 176,000 people living in the area of of $53.41 \mathrm{~m}^{2}$, which resulted in the population density of 3,296 persons $/ 1 \mathrm{~km}^{2}$ ). The share of Krzyki in the number of flats commissioned in Wrocław in 2017 was the greatest of all the five former districts and amounted to circa $38 \%$, while for the area of the flats it was ca. $37 \%$. Psie Pole is the last of the areas of interest, situated in the north of Wrocław, most remote from the city centre and ranked as 5 th among the districts for population density (circa 1,020 persons per $1 \mathrm{~km}^{2}$ ). It has the area of nearly $98 \mathrm{~km}^{2}$, and its share for the number of flats commissioned in 2017 amounted to $21 \%$, while for the area of residential premises it was ca. $23 \%$. With regard to a lower price for $1 \mathrm{~m}^{2}$ in this district (on the secondary market and for the medium and large flats in particular), on average larger flats were bought than in other districts (in 2017 the mean usable area of a commissioned flat was around $62.6 \mathrm{~m}^{2}$ ). The mean usable area of a flat commissioned in Wrocław was almost $60 \mathrm{~m}^{2}$ in 2017, and the highest value was reached in 2011 (circa $67 \mathrm{~m}^{2}$ ). Krzyki and Psie Pole are the only two out of the five territorial units of Wrocław which reached a positive birth rate in 2017, amounting to 3.5/1000 people and 3.9/1000 people, respectively [Statistical Yearbook ... 2018]. With regard to the number of business entities Fabryczna and Krzyki were the leaders, Fabryczna and Psie Pole had the highest number of industrial entities, while the majority of service providing entities were based in Fabryczna and Stare Miasto, which was not included in the study [Local Data Bank...].

The mean transaction price of $1 \mathrm{~m}^{2}$ of residential premises with a usable area between 30 and $50 \mathrm{~m}^{2}$ was analysed first. The analysis included residential premises built in and after 2006. The dynamics of change in the average price between 2010 and 2017 in the former districts of Fabryczna, Krzyki and Psie Pole is presented in Figure 1. The prices have been stripped of the inflation rate by applying the annual values of the price change index for consumer goods and services in Poland, quoted by Statistics Poland; the data are presented in fixed prices of 2010 . 
In 2010 the highest mean price of $1 \mathrm{~m}^{2}$ was achieved in the districts of Krzyki and Fabryczna on secondary markets. In 2011 the highest mean price was recorded on the primary market in Krzyki, while in 2012 it was on the secondary market in Psie Pole. Since 2013, among residential premises with an area of 30-50 $\mathrm{m}^{2}$ the highest mean price was recorded continuously for the secondary market flats in Krzyki up to 2017. The mean price of $1 \mathrm{~m}^{2}$ on the secondary market in Fabryczna demonstrated the greatest volatility, however significant fluctuations were also observed for the primary market in Krzyki. Except for the primary market in Krzyki and secondary market in Psie Pole, in 2017 the current price went up compared to the previous years for all the other cases - the highest increase was observed on the primary market in Psie Pole, while the lowest one on the primary market in Fabryczna, but according to fixed prices of 2010 the mean price of $1 \mathrm{~m}^{2}$ in 2017 in each district, except for the primary market in Psie Pole, was lower than in 2010. A clear declining trend applied only to the mean price on the secondary market in Psie Pole, where the fixed price for $1 \mathrm{~m}^{2}$ in 2010 amounted to 6,200 PLN, in 2013 it was approximately 5,300 PLN but only 4,900 PLN in 2017.

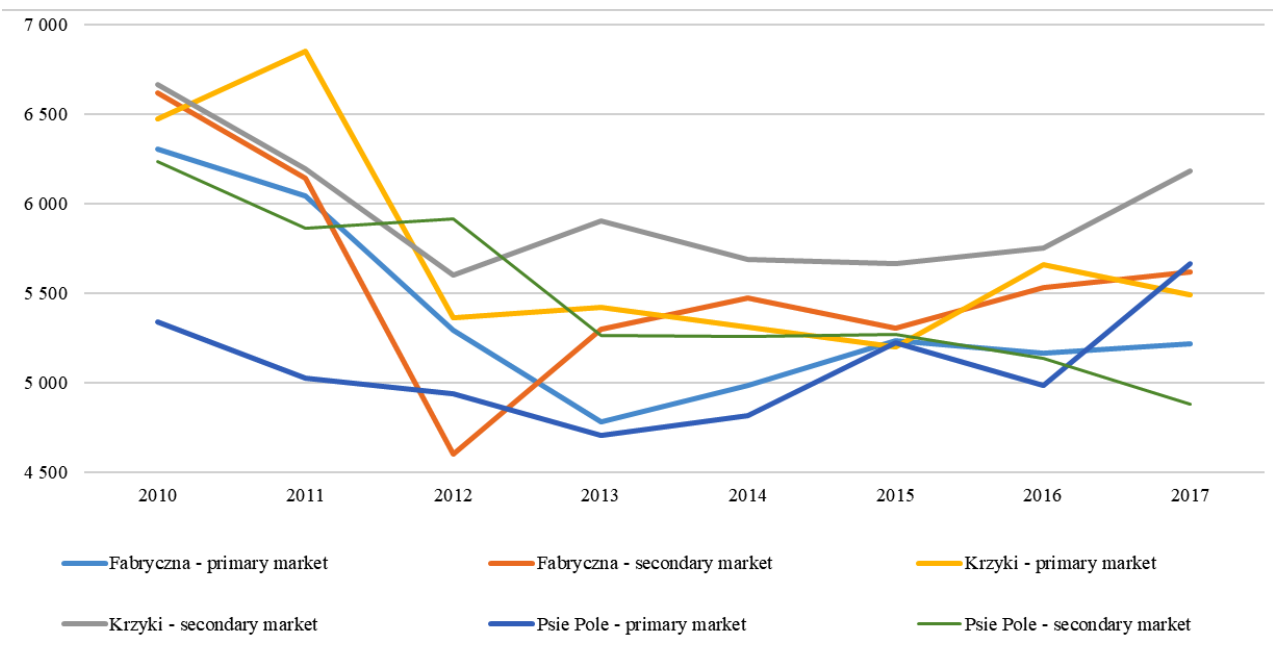

Figure 1. Comparison of mean price for $1 \mathrm{~m}^{2}$ of residential premises with an area from 30 to $50 \mathrm{~m}^{2}$ in selected former districts of Wrocław between 2010 and 2017 (fixed prices of 2010)

Source: own study based on data from the AMRON Centre database and data from Statistics Poland.

In the group of flats with a usable area of $30-50 \mathrm{~m}^{2}$ in 2017, the lowest price was reached by secondary market flats in the Psie Pole district (around 5,350 PLN $/ \mathrm{m}^{2}$ in current prices and around 4,900 PLN/ $\mathrm{m}^{2}$ in fixed prices of 2010), while the highest secondary market price was recorded in the district of Krzyki (nearly $6,800 \mathrm{PLN} / \mathrm{m}^{2}$ and nearly $6,200 \mathrm{PLN} / \mathrm{m}^{2}$, respectively). The most balanced prices in all districts (save for Krzyki - secondary market) were observed in 2015; the mean price 
amounted then to 5,200-5,300 PLN/ $\mathrm{m}^{2}$ according to fixed prices of 2010 and nearly $5,700 \mathrm{PLN} / \mathrm{m}^{2}$ only on the secondary market in Krzyki.

Then an analysis of the mean price of residential premises was carried out for the second category, i.e. $71-90 \mathrm{~m}^{2}$ in fixed prices of 2010 (see Figure 2). Similarly to the case of smaller flats, since 2013 the secondary market residential premises in the district of Krzyki were reaching the highest mean price. The mean price of $1 \mathrm{~m}^{2}$ on the secondary market in Krzyki revealed the greatest volatility but high fluctuations (over 10\%) were also observed on the primary market in the Fabryczna district. The year of 2013 saw the greatest drop in the mean real prices except for Krzyki. It was then when the prices were most balanced on the primary and secondary market in the districts of Fabryczna and Psie Pole (fixed prices: 4,000-4,600 PLN $/ \mathrm{m}^{2}$, current prices: 4,400-5,000 $\mathrm{PLN} / \mathrm{m}^{2}$ ).

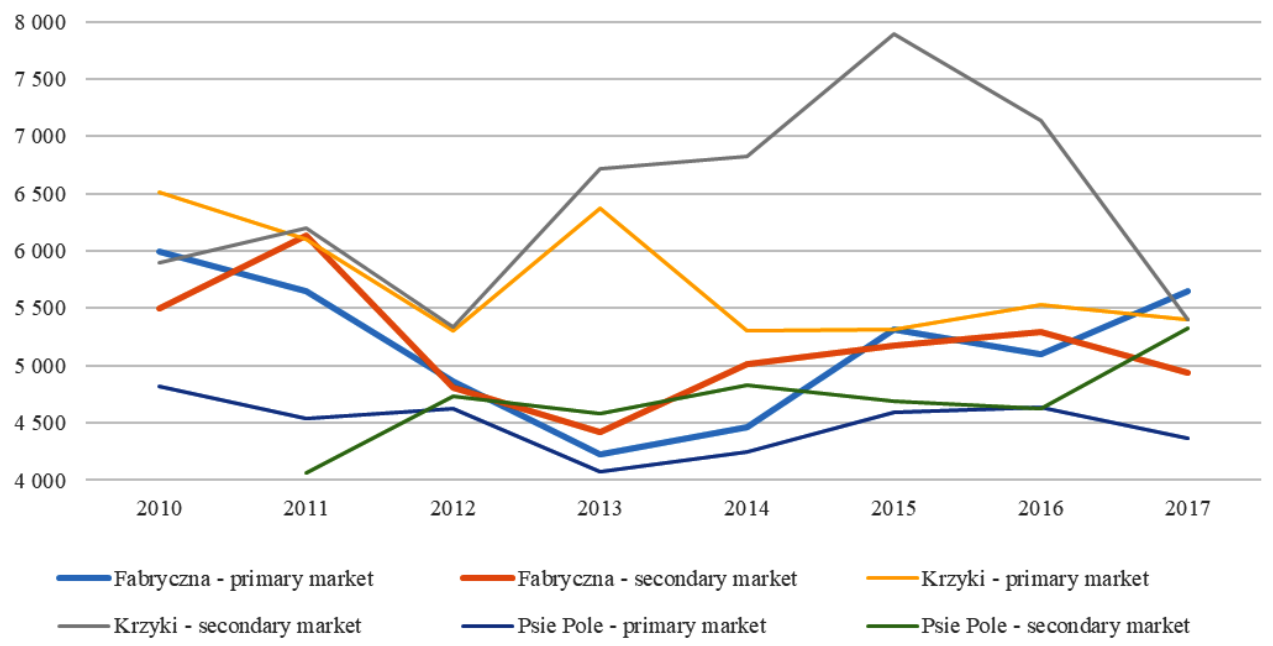

Figure 2. Comparison of mean price for $1 \mathrm{~m}^{2}$ of residential premises with an area from 71 to $90 \mathrm{~m}^{2}$ in selected former districts of Wrocław between 2010 and 2017 (fixed prices of 2010)*

${ }^{*}$ There are no data available on secondary market transactions in the Psie Pole district in 2010; due to a lack of data the mean secondary market price for Psie Pole in 2013 was identified based on transactions from sales agreements and preliminary agreements for flats with an area of $61-90 \mathrm{~m}^{2}$.

Source: own study based on data from the AMRON Centre database and the data from Statistics Poland.

The year of 2017 saw an increase in the prices on the primary market in Fabryczna and the secondary market in Psie Pole for flats with a usable area of 71$-90 \mathrm{~m}^{2}$. In 2017, primary market flats in the Psie Pole district registered the lowest prices (around 4,800 PLN $/ \mathrm{m}^{2}$ in current prices and less than $4,400 \mathrm{PLN} / \mathrm{m}^{2}$ in fixed prices of 2010), while the highest price - on the primary market as well - was observed in the district of Fabryczna (nearly 6,200 PLN $/ \mathrm{m}^{2}$ and over 5,600 PLN/ $\mathrm{m}^{2}$, respectively). 


\section{Comparison of price volatility on the primary and secondary markets in Wroclaw between 2010 and 2017}

Table 2 presents the value of the coefficient of variation for each studied variable for the district and market, analysing the changes in the mean price in the 2010-2017 period (discussed in Section 4).

Table 2. Coefficient of variation of mean fixed prices of residential premises with an area of 30-50 and $71-90 \mathrm{~m}^{2}$ on the primary and secondary markets in selected districts of Wrocław between 2010 and 2017 (in \%, fixed prices of 2010)

\begin{tabular}{|l|l|c|c|}
\hline \multicolumn{1}{|c|}{ District } & \multicolumn{1}{c|}{ Type of market } & $30-50 \mathrm{~m}^{2}$ & $71-90 \mathrm{~m}^{2}$ \\
\hline Fabryczna & Primary & 9.68 & 11.92 \\
\hline Fabryczna & Secondary & 10.77 & 9.91 \\
\hline Krzyki & Primary & 10.58 & 8.92 \\
\hline Krzyki & Secondary & 6.14 & 13.75 \\
\hline Psie Pole & Primary & 6.10 & 5.37 \\
\hline Psie Pole & Secondary & 8.51 & 7.95 \\
\hline
\end{tabular}

Source: own study based on data from the AMRON Centre database and the data from Statistics Poland.

The prices of secondary market flats with an area of $71-90 \mathrm{~m}^{2}$ in the district of Krzyki revealed the greatest volatility over time. Fairly high price volatility in the case of larger flats was also observed on the primary and secondary market in the Fabryczna district. For smaller flats, the highest volatility over time applied to the fixed transaction prices on the secondary market in Fabryczna and the primary market in Krzyki.

The variation between the districts was also examined separately for each year, according to the division into primary and secondary market. The results are presented in Table 3.

Table 3. Coefficient of variation of the mean prices of residential premises with an area of 30-50 and $71-90 \mathrm{~m}^{2}$ on the primary and secondary market, between the studied Wrocław territorial units per year in the period 2010-2017 (in \%)

\begin{tabular}{|c|l|r|r|r|r|r|r|r|r|}
\hline $\begin{array}{c}\text { Area } \\
\left(\text { in }^{2}\right)\end{array}$ & Type of market & 2010 & 2011 & 2012 & 2013 & 2014 & 2015 & 2016 & 2017 \\
\hline $30-50$ & primary & 10.15 & 15.32 & 4,39 & 7.91 & 5.01 & 0.37 & 6.65 & 4.13 \\
\cline { 2 - 10 } & secondary & 3.64 & 2.93 & 12.77 & 6.55 & 3.91 & 4.07 & 5.75 & 11.74 \\
\hline $71-90$ & primary & 15.01 & 14.81 & 7.03 & 26.25 & 11.97 & 8.21 & 8.70 & 13.27 \\
\cline { 2 - 9 } & secondary & 7.48 & 22.23 & 6.58 & 24.45 & 19.85 & 29.11 & 22.84 & 4.72 \\
\hline
\end{tabular}

Source: own study based on data from the AMRON Centre database and the data from Statistics Poland. 
The greatest differences in the prices among the former districts were observed for larger flats: on the secondary market in 2011, 2013, 2015 and 2016, and on the primary market in 2013 . The differences were definitely less significant for smaller flats.

Based on the performed analysis it cannot be clearly stated whether the primary or the secondary market was characterised by higher price volatility in the study period, but it can be concluded that the prices of larger flats revealed higher volatility over time (regarding former city districts).

\section{Discussion}

In theory, imbalance and adaptation to the market are the main subject matter of studies in relation to the housing market; the studies pertain both to supply and demand. A number of subjective and objective factors affect the level of prices of residential premises. With regard to specific characteristics of the real estate and property market, subjective factors play an important role. This makes the forecasting of changes in the prices of real estate difficult, and it is often burdened with error. For instance, the results of the studies presented by R. Trojanek for Wrocław show that between 1997 and 2010 the business fluctuations in Poland justified over 60\% of the changes in $1 \mathrm{~m}^{2}$ of residential premises in Wrocław, which means that factors other than the fluctuations mentioned above, had a significant impact on the prices on real estate market [2011].

The high demand for flats placed producers of residential premises in Wrocław (real estate developers in particular) in a stronger position than buyers (a dynamic demand increase at a constant supply in a short period of time). This situation resulted mainly from social and economic development, a significant influx of people (including immigrants from Ukraine), dynamic labour market development, increase in mean salary, and the low interest rates of bank deposits etc. The trend contributed to the increase in the prices of housing real estate, including residential premises. Only with minor exceptions did the mean current prices of residential premises stay on a relatively high and rising level, but the real transaction prices (of 2010, including the price increase index for consumer goods and services) went down.

Bigger and growing differences in the average transaction price of $1 \mathrm{~m}^{2}$ of residential premises between flats constructed in new and old technology were observed for larger flats (with an area of 71-90 $\mathrm{m}^{2}$ ), while in the case of smaller flats $\left(30-50 \mathrm{~m}^{2}\right)$ the differences were less significant but they were growing gradually since 2013. It needs to be highlighted that for flats built since 2006 in low-rise multifamily buildings, the mean transaction price of $1 \mathrm{~m}^{2}$ varied only slightly depending on the flat area and the price of $1 \mathrm{~m}^{2}$ decreased only slightly with the increase in the flat usable area. 
When comparing the differences in the average fixed prices according to transactions concluded in 2010 and 2017, between the districts of Fabryczna, Krzyki and Psie Pole, and considering flats with an area of $30-50 \mathrm{~m}^{2}$ built after 2005 , one can see that they decreased on the primary market and increased on the secondary market. The price of $1 \mathrm{~m}^{2}$ in Psie Pole was definitely the lowest on the primary market in both years, while the difference was reduced in the mean fixed transaction price between the two other former districts in 2017 compared to 2010. On the secondary market in 2017 the difference in the prices between the three studied units was fairly low but in earlier years (especially between 2013 and 2017) it was definitely higher, whereby the area of Krzyki stood out with its highest mean transaction price. Analysis of former districts revealed that the prices of bigger flats showed greater volatility over time.

\section{Conclusions}

The author discussed the differences in the mean transaction price of $1 \mathrm{~m}^{2}$ of residential premises in three out of five territorial units of Wrocław. The research was carried out for the period 2010-2017. The main goal of the paper was to present the differences in the mean transaction price in the following categories: the useable area of the flat, the type of market (primary or secondary) and the building technology. Wrocław is attractive in terms of housing, as evidenced on the primary and secondary market of residential premises. In the future, the differences between the mean price of $1 \mathrm{~m}^{2}$ of a flat built using new and old technology will grow - those built with the use of a new one will be more attractive. This trend is currently noticeable mainly in the market of relatively large premises $\left(71-90 \mathrm{~m}^{2}\right)$. The differences in prices between territorial units of Wrocław will also widen, more notably than on the secondary market. In the period under analysis, especially in 2013-2016, the position of one of the units - Krzyki, considered to be more prestigious, was strengthened. The trend was also more evident in the category of larger flats.

\section{References}

Centre for Real Estate Trade Market Analysis and Monitoring (AMRON Centre) database (accessed 20.07.2019-27.07.2019).

De Palma A., Picard N., Waddell P., 2007, Discrete choice models with capacity constraints: An empirical analysis of the housing market of the greater Paris region, Journal of Urban Economics, vol. 62 , no. 2 , pp. 204-230.

Goodman A.C., 1981, Housing submarkets within urban areas: Definitions and evidence, Journal of Regional Science, vol. 21, no. 2, pp. 175-185.

Key T. et al., 1994, Understanding the property cycle, RICS, London.

Kucharska-Stasiak E., 1997, Nieruchomość a rynek, Wydawnictwo Naukowe PWN, Warszawa.

Local Data Bank, https://bdl.stat.gov.pl/BDL/dane/podgrup/temat (accessed 27.07.2019). 
Maclennan D., Munro M., Wood G., 1987, Housing choices and the structure of housing markets, Scandinavian Housing and Planning Research, 4, sup1., pp. 26-52.

Maclennan D., Tu Y., 1996, Economic perspectives on the structure of local housing systems, Housing Studies, no. 11, pp. 387-406.

Meen G., 2001, Modelling Spatial Housing Markets: Theory, Analysis and Policy, Kluwer Academic Press, New York.

Meen G., 2016, Spatial housing economics: A survey, Urban Studies, no. 53 (10), pp. 1987-2003.

Statistical Yearbook of Wrockaw City 2018, Statistical Office in Wrocław, Wrocław.

Shiller R.J., 1991, Arithmetic repeat sales price estimators, Journal of Housing Economics, vol. 1, pp. 110-126.

Sirmans G.S., Macpherson D.A., Ziets E., 2005, The composition of hedonic pricing models, Journal of Real Estate Literature, no.13(1), pp. 3-46.

Trojanek R., 2011, Wpływ wahań koniunkturalnych na lokalne rynki mieszkaniowe, Studia i Materiały Towarzystwa Naukowego Nieruchomości, vol. 19, no. 1, pp. 81-94.

Tu Y., 1997, The local housing sub-market structure and its properties, Urban Studies, vol. 34, no. 2, pp. 337-353.

Weibull J.W., 1983, A dynamic model of trade frictions and disequilibrium in the housing market, Scandinavian Journal of Economics, no. 85, pp. 373-392. 